\title{
多層階地下駐車場の換気性状の検討 \\ 地下駐車場の換気性状・換気効率に関する研究その 2
CFD STUDIES ON VENTILATION EFFICIENCY IN A MULTI STORIED UNDERGROUND CAR PARK

Study on ventilation efficiency in underground car parks Part 2

\author{
吉野 - - , 近藤靖 史**, 田所祐人*** \\ Hajime YOSHINO, Yasushi KONDO and Yuto TADOKORO
}

\begin{abstract}
This paper presents the results of CFD simulation on the ventilation efficiency in a multi storied underground car park. In this study the influence of supply/exhaust air imbalance of mechanical ventilation system, and the buoyancy effect of heat from ground and vehicles were studied with the age of air obtained from CFD.

The results of this paper are following;

(1) In Casel (supply air volume= exhaust air volume), the distribution of the age of air was almost same in each floor. There fore it is easy to plan the ventilation system such as the layout, of the high velocity fan-diffuser unit for the stagnant region.

(2) In Case2 (supply air volume < exhaust air volume), the airflow through the ramps was activated and the difference in the ventilation efficiency of each floors was observed. In this case, the planning of ventilation system becomes relatively difficult.

(3) In Case3 (supply air volume > exhaust air volume), the airflow through the ramps was activated and the difference in the ventilation efficiency of each floors was observed, as same as in Case2.

(4) The buoyancy effect due to the heat transfer between indoor air and ground walls on the distribution of temperature and the age of air was observed in the lowest floor in summer and winter.

(5) When the heat generation from vehicles was considered in the simulation, the air diffusion was activated due to the buoyancy effect.
\end{abstract}

Keywords : Underground car parks, Ventilation efficiency, Air imbalance, Buoyancy, CFD 地下駐車場, 換気効率, エアアンバランス, 浮力, 数值流体力学

1.序

都市部では都市活動が進展するに伴い駐車場の建設に必要な敷地 の確保が困難になる。したがって、限られた敷地で駐車スペースを 確保するには、地上に高く建設するか、あるいは地下に哚く建設す るかのどちらかになる。このような背景から都市部では立体駐車場 6)および地下式駐車場(以下、地下駐車場と記す)が多く建設されてい る。また、事務所ビル、ホテルなどの商用ビルの多くは、地下駐車 場を併設する場合が多く、さらに地下 2 階、3 階などの多層階とな っている地下駐車場が多くなっている。このような多層階地下駐車 場では、各階に連絡斜路(以下、スロープと記す)が設けられている。

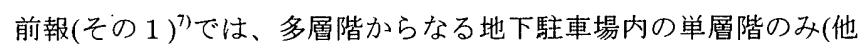
階一通じるスロープを封鎖)を対象として実測および CFD(Computational Fluid Dynamics)解析を行い、換気性状を詳細に検 討した。一方、実際の多層階地下駐車場においては、

(1) 給排気バランス䛨1)のずれ

(2) 地盤や壁からの熱移動

(3) 自動車からの発熱

などにより、スロープ内に流れが生じる可能性がある裎2)。このよう な場合、換気性状を検討する際には多層階を同時に扱う必要がある。

そこで本報(その 2)では、上記(1)について機械換気設備の給排気
量がバランスしていない等温の状態を想定し検討した。また(2)につ いては夏季と冬季について地盤からの熱移動に起因する地下駐車場 内の温度差が換気性状に与える影響を検討した。(3)ついては、自 動車の発熱によって浮力が生じている状態を想定し、CFDにより各 階の換気性状を検討した。

\section{2.スロープの配置と通行区分による地下駐車場の類型化}

多層階地下駐車場のスロープ の多くは、スロープの位置がセン ターにある場合とサイドにある場合辣引 の 2 種に分類することができ

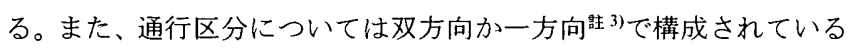
事例が多い6)。そこで図 1 に示すような 3 層(地下 3 階)からなる多層 階地下駐車場モデルを対象として代表的な平面・断面計画に基づい て、タイプ A、B、C、Dの4つのタイプを検討した。

\section{3.給排気バランスのずれによる影響}

\section{1 解析概要}

図1の4タイプに対して、各階において一方向流れ的な換気(ピスト ンフロー)を想定し、給排気口を配置した多層階地下駐車場モデルを 解析する。解析モデルの一例を図 2 に示す。各階の容積は、 $42.0 \mathrm{~m}^{\mathrm{W}} \times 42.0 \mathrm{~m}^{\mathrm{D}} \times 4.0 \mathrm{~m}^{\mathrm{H}}=7,056 \mathrm{~m}^{3}$ とした。解析ケースは、4タイプの

\footnotetext{
本論文は日本建筑学会大会学術講演会(2000年)，同関束支部研究発表会 (2000年), 空気調和衛生工学会学術講演会 (2000年)において発表した内容をもとにしている(文献1 5)。 *武蔵工業大学大学院工学研究科 博士後期課程 Graduate Student, Dr. of Engineering Course, Musashi Inst. of Tech., Tonets (東洋熱工業(侏)

** 武藏工業大学工学部建築学科 教授・博士(工学)

*** 森ビル烌) 修士(工学)

(研究当時, 武蔵工業大学 大学院生) Corporation

Prof., Dept. of Architecture, Faculty of Engineering, Musashi Inst. of Tech., Dr. Eng. Mori Building Co., Ltd., Formerly Graduate Student of Musashi Inst. of Tech., M. Eng.
} 
各々について給排気がバランスしている Case 1(給気量=排気量)、場

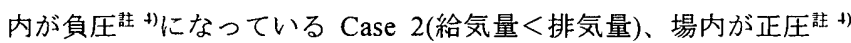
となっている Case 3(給気量>排気量)の 3 パターンを検討する(表 1 参照)。また、表 2、表 3 に示す条件で解析を行った。

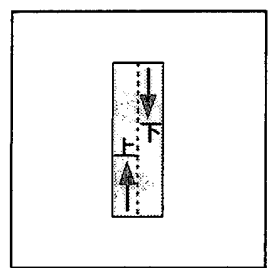

タイプA(平面) 双方向スロー配置

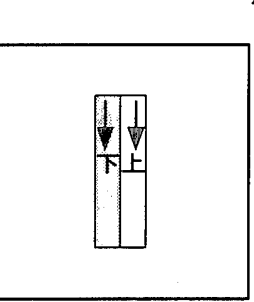

タイプC(平面) センター配置

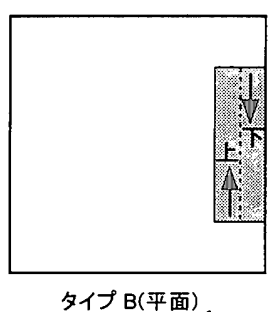

タイプB(平面)

双方向配置

タイプ $A, B$ (双方向スロープ)

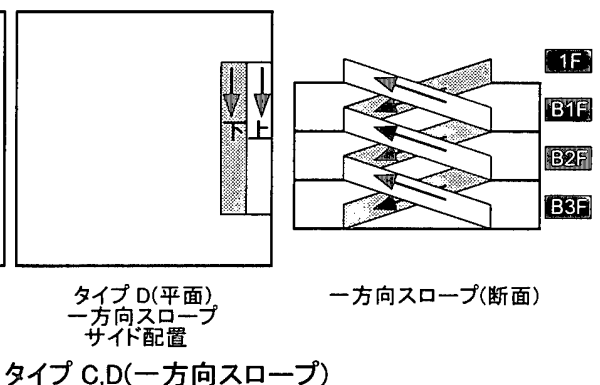

図 1 地下駐車場の代表的な平面·断面計画

表 1 給排気バランスの影響を想定した解析ケース

\begin{tabular}{|c|c|c|c|}
\hline \multirow{2}{*}{\multicolumn{2}{|c|}{ 検討 Case およびタイプ }} & \multicolumn{2}{|c|}{ 平面·断面計画 } \\
\hline & & \multirow{2}{*}{$\frac{\text { スロープ位置 }}{\text { センター }}$} & \multirow{2}{*}{$\frac{\text { 通行区分 }}{\text { 双方向 }}$} \\
\hline \multirow{4}{*}{$\begin{array}{c}\text { 給気=排気 } \\
\text { Case } 1\end{array}$} & Case 1-A & & \\
\hline & Case 1-B & サイド & 双方向 \\
\hline & Case 1-C & センター & 一方向 \\
\hline & Case 1-D & サイド & 一方向 \\
\hline \multirow{4}{*}{$\begin{array}{c}\text { 給気く排気 } \\
\text { Case } 2\end{array}$} & Case 2-A & センター & 双方向 \\
\hline & Case 2-B & サイド & 双方向 \\
\hline & Case 2-C & センター & 一方向 \\
\hline & Case 2-D & サイド & 一方向 \\
\hline \multirow{4}{*}{$\begin{array}{c}\text { 給気〉排気 } \\
\text { Case } 3\end{array}$} & Case 3-A & センター & 双方向 \\
\hline & Case 3-B & サイド & 双方向 \\
\hline & Case 3-C & センター & 一方向 \\
\hline & Case 3-D & サイド & 一方向 \\
\hline
\end{tabular}

\section{表 2 境界条件}

\begin{tabular}{|c|c|c|}
\hline \multirow{2}{*}{ 給 氮 } & $100 \%$ & $\begin{array}{l}\text { 面䅡: } 42 \times 6=252\left[\mathrm{~m}^{2}\right], \\
\text { 吹出し風速: } 0.0777[\mathrm{~m} / \mathrm{s}] \\
\text { 外気導入量: }: 0.489\left[\mathrm{~m}^{3} / \mathrm{h}\right]\end{array}$ \\
\hline & $90 \%$ & $\begin{array}{l}\text { 面積: } 42 \times 6=252\left[\mathrm{~m}^{2}\right], \\
\text { 吹出し風速: } 0.070[\mathrm{~m} / \mathrm{s}] \\
\text { 外気導入量: } 63,504\left[\mathrm{~m}^{3} / \mathrm{h}\right]\end{array}$ \\
\hline \multirow{2}{*}{ 排 気 } & $100 \%$ & $\begin{array}{l}\text { 面䅡: } 42 \times 6=252\left[\mathrm{~m}^{2}\right] \text {, } \\
\text { 吹出し風速: } 0.0777[\mathrm{~m} / \mathrm{s}] \\
\text { 排気暴: }: 0,489\left[\mathrm{~m}^{3} / \mathrm{h}\right]\end{array}$ \\
\hline & $90 \%$ & $\begin{array}{l}\text { 面楥: } 42 \times 6=252\left[\mathrm{~m}^{2}\right] \text {, } \\
\text { 吹出し風速: } 0.070[\mathrm{~m} / \mathrm{s}] \\
\text { 排気量: } 63,504\left[\mathrm{~m}^{3} / \mathrm{h}\right]\end{array}$ \\
\hline 地上開口部 & \multicolumn{2}{|c|}{ 自然流入流出 ${ }^{\text {(1) }}$} \\
\hline 壁 面 & \multicolumn{2}{|c|}{ (速度) 一般化対数則 } \\
\hline
\end{tabular}

流入境界条件としての乱流エネルギー $\mathrm{k}_{\mathrm{in}}$ 、kの散逸率 $\varepsilon_{\mathrm{in}}$ は、

以下の式を用いて求める。

$$
\mathrm{k}_{\mathrm{in}}=\left(U_{\text {in }} / 10\right)^{2}\left[\mathrm{~m}^{2} / \mathrm{s}^{2}\right] \quad \varepsilon_{\text {in }}=0.09^{3 / 4} \cdot \mathrm{k}_{\mathrm{in}}{ }^{3 / 2} / \ell \mathrm{m}\left[\mathrm{m}^{2} / \mathrm{s}^{3}\right]^{8)}
$$

ここで、 $U$ 、流入速度、 $\ell m=1 / 2 \mathrm{~L}$ 、L:吹出口短辺

\section{2 解析結果および考察}

以下に示寸解析結果辣(は、スロープがセンターに配置され、双方 向スロープの場合(タイプA)のものであり、SVE3(無次元化した空気 齢、表 3 参照)を用いて考察を行う。

(1) Case 1(給気量二排氞量 図 3)

双方向スロープ・センター配置(Case 1-A)の各階の呼吸域高さにお ける結果を図 3 に示す。呼吸域高さにおける換気性状は、各階でほ ぼ同等である。他階に通じるスロープ内では、空気齡の值が大きい。 すなわち、スロープ内の流れは停滞しており、これが各階の流れ場 に与える影響は小さいものと考えられる。

\section{表 3 計算条件}

・メッシュ分割は、

タイプ A : $68(\mathrm{x}) \times 57(\mathrm{y}) \times 53(\mathrm{z})=205,428$ (メッシュ)

タイプ B: $66(x) \times 75(y) \times 56(z)=277,200$ (メッシュ)

タイプ C: $81(x) \times 64(y) \times 61(z)=316,224$ (メッシュ)

タイプ D : $81(x) \times 72(y) \times 61(z)=355.752($ メッシュ)

$\cdot X 、 Y 、 Z$ 座標系は図 2 を参照

\section{・乱流モデル: 標準 $\mathrm{k}-\varepsilon$ モデル}

·移流項の差分スキーム:QUICK

·濃度翰送方程式の差分スキーム: 1 次風上

3 章で示す解析ケースでは等温場を対象とし、熱輸送方程式は解いてい ない。

·SVE3 ${ }^{97}$ とは、室内全域に一棑に、、污染物質が発生し続けるとした場合、給気口 から新鮮空気を入れたときの拡散物質濃度と污染物質の瞬時一様濃度との 比である。

$\operatorname{SVE} 3(\mathrm{X})=\mathrm{C}(\mathrm{X}) / \mathrm{Cs}$

ただし、Cs=q/Q すなわち $S V E 3(X)$ は位置 Xにおける吹出空気の空気龄指 標である。

$\mathrm{C}(\mathrm{X})$ : 空間で一様に $\mathrm{q}[\mathrm{kg} / \mathrm{s}]$ の発生があった場合の位置 Xにおける濃度 $\left[\mathrm{kg} / \mathrm{m}^{3}\right]$ Cs: 瞬時一様拡散濃度 $\left[\mathrm{kg} / \mathrm{m}^{3}\right]$

$\mathrm{q}:$ 污染質発生照 $[\mathrm{kg} / \mathrm{s}]$

$Q:$ 換気量 $\left[\mathrm{m}^{3} / \mathrm{s}\right]$

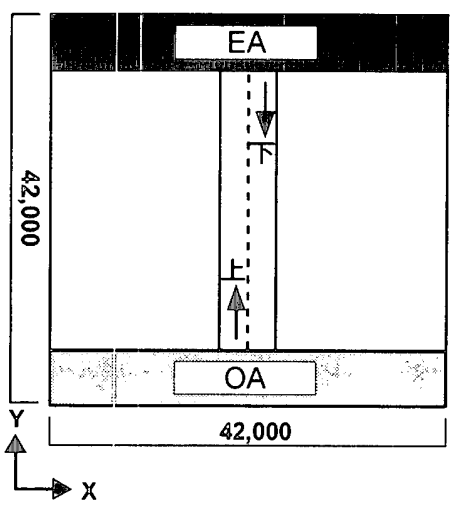

(a)平面

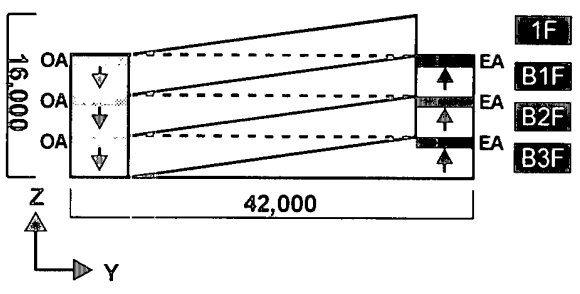

(b) 断面

図 2 解析モデルの例(タイプAの場合)[単位: $\mathrm{mm}$ ] 
このように各階の換気性状が同等になることによって、適切な換 気計画を行うことができると考えられる。例えば、前報(その 1$)^{7)}$ で 示したように必要に応じて誘引誘導ノズルなどの換気性状を向上さ せる換気装置を滞留域と予想される場所に対し設置睡》するなど、対 応も容易である。

一方向スロープ・センター配置(Case 1-C)およびサイドスロープ (Case 1-B、Case 1-D)の結果においてもセンタースロープと同様な傾 向を示した(図省略)。

(2) Case 2(給気量<排気量 図 4)

双方向スロープ・センター配置(Case 2-A)の各階の呼吸域高さにお ける結果を図 4 に示す。各階での呼吸域高さにお打換気性状に差 異が見られた。給気量に対して排気量が多いため、地下 1 階では外 気に面したスロープの地上階開口部から新鮮外気が流入し、呼吸域 高さの換気性状が良好となった。しかし、地下 2 階、3 階と階が下 がるに伴い、スロープ内では他階から空気齢の值が大きい空気がス
ロープを通じて流れ込むこととなり、換気性状がやや悪くなる傾向 を示した。このように、各階の換気性状に差異がある場合、適切な 換気計画を行うことは、容易ではなくなると考えられる。

一方向スロープ・センター配置(Case 1-C)およびサイドスロープ (Case 2-B、Case 2-D)の結果においてもセンタースロープと同様な傾 向を示した(図省略)。

(3) Case 3(給気量 $>$ 排気量 図 5)

双方向スロープ・センター配置(Case 3-A)の各階の呼吸域高さにお ける結果を図 5 に示す。地下 3 階に比べ地下 1 階の方が空気齢の值 が大きく、各階の換気性状に差異が見られた。これは排気量に対し て給気量が多いため、各階から空気齢の值が大きい空気の一部がス ロープを通じて上階へ流れ込んだことによると考えられる。

一方向スロープ・センター配置(Case 1-C)およびサイドスロープ (Case 3-B、Case 3-D)の結果においてもセンタースロープと同様な傾向 を示した(図省略)。

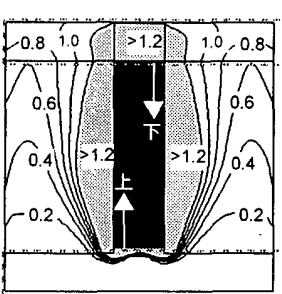

地下1階平面

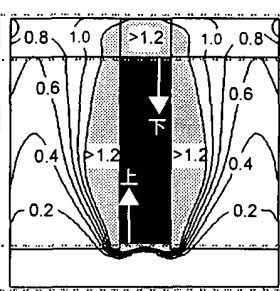

地下2階平面

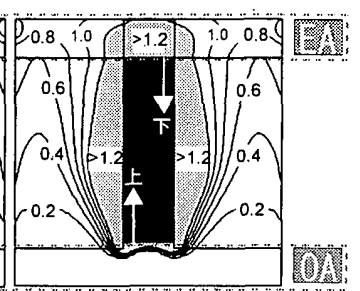

地下3階平面

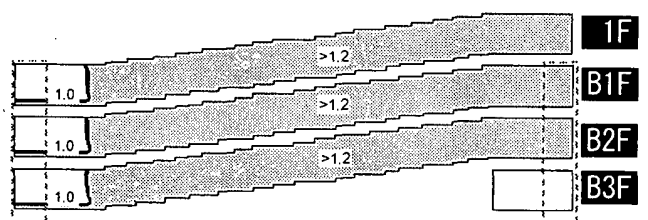

as

図3 空気路分布(SVE3)(平面図はFL+1500mm)

Case 1-A(双方向スロープ・センター配置)

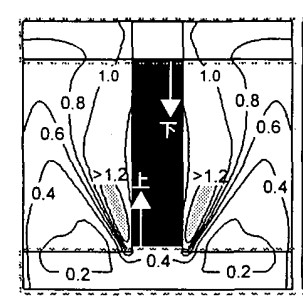

地下1階平面

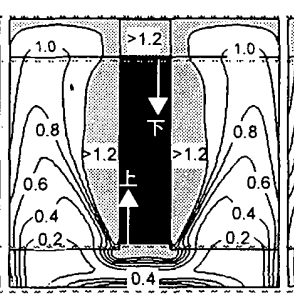

地下2階平面

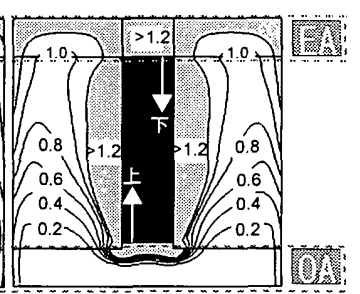

地下3階平面

図4 空気跉分布(SVE3)(平面図はFL $+1500 \mathrm{~mm}$ )

Case 2-A(双方向スロープ・センター配置)

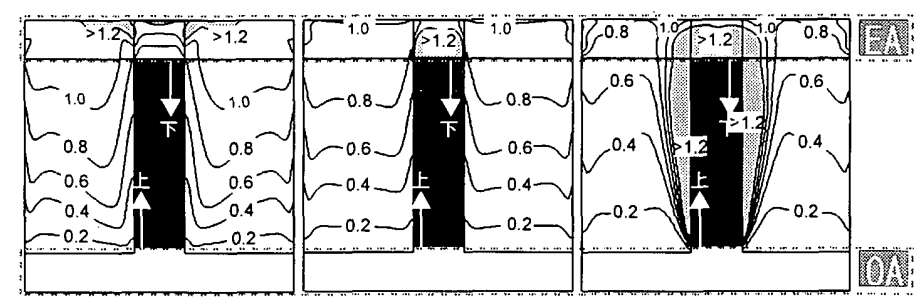

地下1階平面
地下2階平面
地下3階平面

図5 空気齢分布(SVE3)(平面図はFL $+1500 \mathrm{~mm}$ )

Case 3-A(双方向スロープ・センター配置)

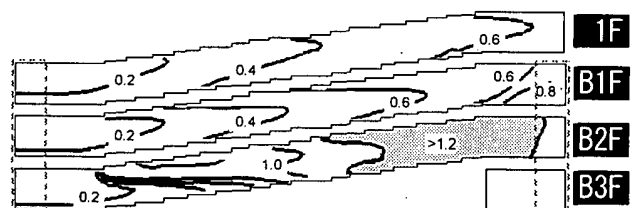

mis

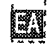




\section{4.地盤からの熱移動の影響 \\ 4.1 解析概要}

本章では、図 1 に示す Case1(給気量＝排気量)のタイプ A(Case1-A) およびタイプ C(Case1-C)を用いて、地盤からの熱移動の影響につい て、夏季と冬季の 2 パターンについて検討する。また、比較のため に等温条件のケースを併せて計 6 ケースの解析を行った(表 4 参照)。

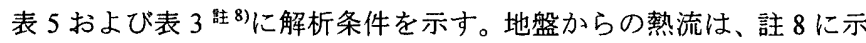
す方法で算定し、これを地盤に接する壁や床に与えた。

\section{2 解析結果および考察}

スロープはセンターにあり、双方向スロープおよび一方向スロー プ(タイプ A、タイプ C)の場合についての夏季および冬季の条件を 想定し、温度分布およびSVE3(無次元化した空気齢)を解析し考察を 行う。

\section{（1)地下駐嘲場内温度分布(表 6,图 6,図 7)}

夏季(Case 1-A-S)および冬季(Casel-A-W)の温度分布を図 6 に、各 Case の空間平均温度の算出結果を表 6 に示す。表 6 より、夏季 $28.6^{\circ} \mathrm{C}$ の外気取り入れを想定した場合(Case1-A-S、Casel-C-S)、空間平均温 度と取入外気との温度差は 1.9 2.7 [ $\left.{ }^{\circ} \mathrm{C}\right]$ であり、また冬季 (Case1-A-W、Case1-C-W)においては $0.8\left[{ }^{\circ} \mathrm{C}\right]$ と、夏季に比べて温 度差が小さい。図 7 に、夏季条件の場合(Case1-A-S)の換気回数と外 気温度と空間平均温度の温度差の関倸を示す。これより、換気回数 が増えるに従い、温度差の減少が見られ、10［回/h］では温度差が 小さい。このように、地下駐車場では法令で義務づけられている換 気回数 $(10[$ 回 $/ \mathrm{h}])$ を想定した場合、夏季·冬季共に空間温度分布 が大きくないものと考えられる。

(2)夏季と冬季の新鮮外気分配(図 8)

図 8 に、タイプA（双方向スロープ・センタ一配置）の場合の、 各階での呼吸域高さにおける空気齢分布の結果を示す。夏季を想定 したケース(Case 1-A-S)は、等温場(Case1-A)と地下 1、2 階でほぼ同 様な結果となった。しかし、最下階である地下 3 階では床面からの 熱流の影響を比較的大きく受けており他階と異なる傾向を示してい る。このように最下階では地盤に接する面積が大きく、浮力の影響 により、冷気が滞留する傾向にある。この結果、最下階で空気齢分 布に差異が見られる。

冬季を想定したケース(Case1-A-W)忙夏季のケース(Case1-A-S) と 同様に、地下 3 階以外は、等温場との差異は顕著ではない。地下 3 階において、地盤に接している床面からの熱流の影響により浮力が 生じ、流れ場がやや活発になっていると思われる。

一方向スロープのケース(Case1-C-S、Case1-C-W)についてもセンタ ースロープのケースと同様な傾向を示した（図省略）。

表 4 地盤からの熱流を想定した解析ケース

\begin{tabular}{c|c|c} 
検討 Case & 検討タイプ & 温熱条件 \\
\hline Case1-A & $\left.\begin{array}{c}\text { タイプA } \\
\text { 双方向スロープ } \\
\text { センター配置 }\end{array}\right)$ & 等温条件 \\
\hline Case1-A-S & 夏季 \\
\hline Case1-A-W & $\begin{array}{c}\text { タイプC } \\
\text { ー方向スロープ } \\
\text { センター配置 }\end{array}$ & 冬季 \\
\hline Case1-C & 等温条件 \\
\hline Case1-C-S & 夏李 \\
\hline Case1-C-W & 冬李 \\
\hline
\end{tabular}

表 5 境界条件および解析条件

\begin{tabular}{|c|c|}
\hline 給 気 & 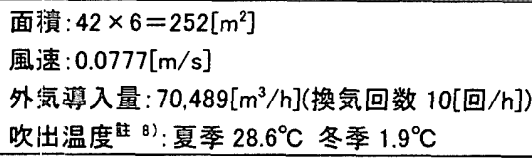 \\
\hline 排 気 & $\begin{array}{l}\text { 面賲: } 42 \times 6=252\left[\mathrm{~m}^{2}\right] \\
\text { 風涑: } 0.0777[\mathrm{~m} / \mathrm{s}] \\
\text { 排氮量: } 70,489\left[\mathrm{~m}^{3} / \mathrm{h}\right]\end{array}$ \\
\hline 地上開口部 & 自燃流入流出社 5) \\
\hline 床·壁面 & $\begin{array}{l}\text { 気流: 一般化対数則 } \\
\text { 熱流: 冬季 } 26.8\left[\mathrm{~W} / \mathrm{m}^{2}\right] \\
\text { 夏季 }-26.6\left[\mathrm{~W} / \mathrm{m}^{2}\right] \text { 想定 }{ }^{\mathrm{at}}{ }^{8} \text { 。 } \\
\end{array}$ \\
\hline
\end{tabular}

熱輸送方程式の差分: $:$ キーム: 1 次風上

表 6 各ケースの外気温度と空間平均温度の温度差

\begin{tabular}{c|c|c} 
Case 名 & 空間平均温度 $\left[{ }^{\circ} \mathrm{C}\right]$ & 取入外気との温度差 $\left[{ }^{\circ} \mathrm{C}\right]$ \\
\hline Case $1-\mathrm{A}-\mathrm{S}$ & 25.9 & -2.7 \\
\hline Case $1-\mathrm{A}-\mathrm{W}$ & 2.7 & +0.8 \\
\hline Case $1-\mathrm{C}-\mathrm{S}$ & 26.7 & -1.9 \\
\hline Case1-C-W & 2.7 & +0.8 \\
\hline
\end{tabular}

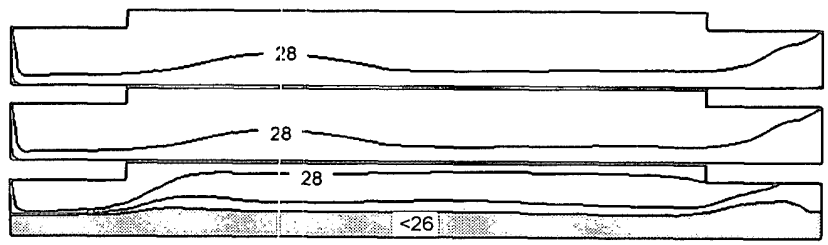

(1)夏季(Case 1-A-S の例、外気温度 : $28.6^{\circ} \mathrm{C}$ )

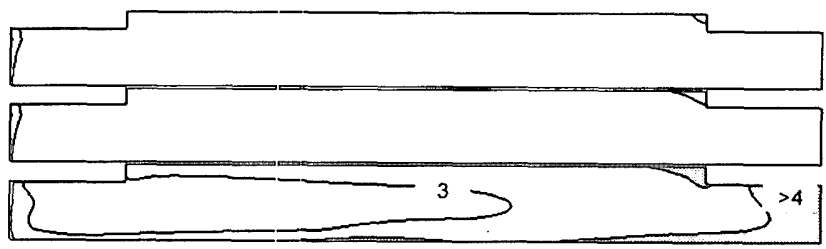

(2)冬季(Case 1-A-W の例、外気温度: $1.9^{\circ} \mathrm{C}$ )

図 6 地搵からの熱流を想定した場合の 红間温度分布(鉛直断面)

単位: $\left[{ }^{\circ} \mathrm{C}\right]$

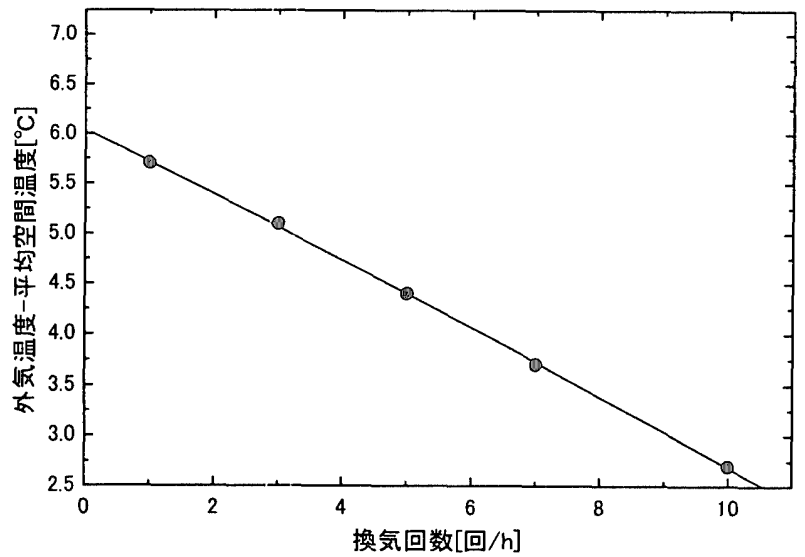

図 7 換気回数と空間平均温度·外気温度差の関係 (Case1-A-S の例) 


\section{5.自動車の発熱の影響}

地下駐車場内の空間温度を形成する要因として地盤からの熱流の 影響と同様に自動車からの発熱蛙9が考えられる。そこで駐車スペー ス上に車をモデル化した発熱体畦9)を想定し、換気性状および温度分 布を検討した。

\section{1 解析概要}

解析モデルは、4 章と同様に図1 に示すCase1(給気量 $=$ 排気量)のタイプ $\mathrm{A}(\mathrm{C}$ ase 1-A)を用いた。4 章に示す地盤からの 熱流の影響を考慮した上で、自動車を想定した直方体 $\left(2.0^{\mathrm{W}} \times 5.0^{\mathrm{D}} \times\right.$ $1.5^{\mathrm{H}} /$ 台)に註 9 に示寸車両からの発熱量を与え検討を行う。発熱し ている車両を各階に均一に分散配置させた場合と各階で不均一な場 合の 2 パターンを検討する。また、比較のため車両からの発熱を考 虑しないケース（Case M-O-S および Case M-O-W）を含め表 7 に示 す 12 ケースを解析した。境界条件、解析条件は表 4、5 に示す条件 とした。図 9 に発熱体(車)の配置例を示す。

\section{2 解析結果および考察}

スロープがセンターに配置され、双方向スロープの場合(タイプ A)の夏季および冬季について、各階でほぼ等間隔に車両からの発熱 を想定したケース(Case M-A-S、Case M-A-W、Case M-B-S、Case M-B-W)、場内の発熱車両に偏りが生じた場合のケース(Case $\mathrm{M}-\mathrm{C}(1)-\mathrm{S} 、$ Case M-C(1)-W、Case M-C(2)-S、Case M-C(2)-W、Case

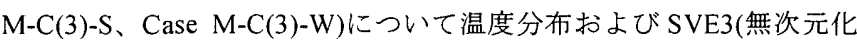
した空気齢)を用いて考察を行う。

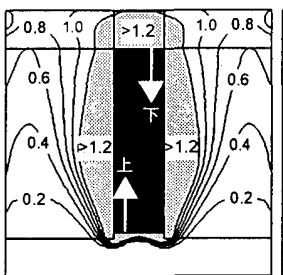

地下 1 階

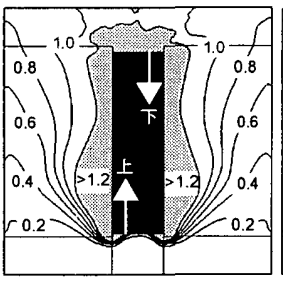

地下 1 階

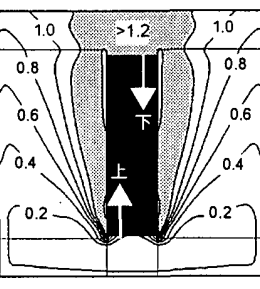

地下 1 階

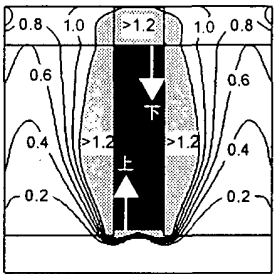

地下 2 階

(1) Case 1-A(等温)

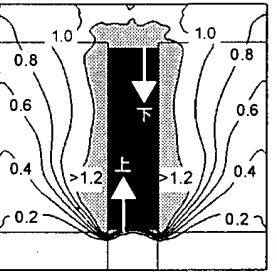

地下 2 階

(2) Case1-A-S(夏季)

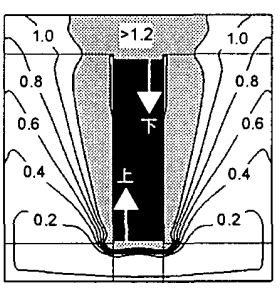

地下 2 階

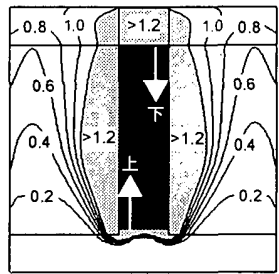

地下 3 階

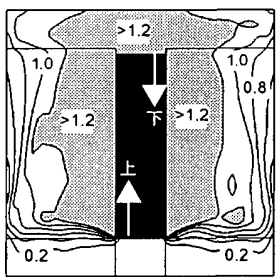

地下 3 階

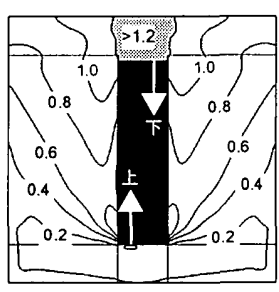

地下 3 階
(3) Case 1-A-W(冬季)

図 8 地盤からの熱流がある場合の

双方向スロープ(タイプA)の各階の空気秢分布(SVE3)
（1)各階に発熱車両がほほ一様に分布する場合(図 10,図 11)

車両からの発熱を考慮しないケース(Case M-0-S)では、4 章に示し た車両を配置しない場合のケース(Casel-A-S) と比較すると、車を 配置したことによる差異は走行スペースにおいては顕著でない。表 8 に車の発熱を想定した各ケースの空間平均温度を示す。発熱を想 定した車が増加するに従い平均温度も当然上昇している。また、図 10 に示す Case M-B-S の鉛直断面の温度分布より、場内の温度に車 からの発熱の影響が見られる。図 11 の空気齢分布の結果では、車両 からの発熱を考慮したことにより、いずれのケースともに移流・拡散 が活性化されていることがわかる。このように車両からの発熱を想 定したケース(Case M-A-S、Case M-B-S)の方が、車両からの発熱を 考虑しないケース(Case M-0-S)より換気性状がやや良好となる傾向 が見られた。これは、車両の発熱による浮力の影響によって場内の 拡散が活性化されたものと考えられる。また、スロープを介した各 階の相互換気による影響は、いずれのケースでも小さい結果となっ た。

冬季を想定したケース（Case M-A-W、Case M-B-W）についても 夏季を想定したケースと同様な傾向を示した（図省略）。

表 7 車両からの発熱を想定した解析ヶース

\begin{tabular}{|c|c|c|c|c|c|}
\hline \multirow{2}{*}{ 検尌 Case } & \multicolumn{4}{|c|}{ 発熱車両数 ${ }^{101}$ /配置車両数 } & \multirow{2}{*}{ 温熱条件 } \\
\hline & 地下 1 階 & 地下 2 階 & 地下 3 階 & 合計 & \\
\hline Case M-0-S & $0 / 48$ & $0 / 48$ & $0 / 48$ & 0 & 夏季 \\
\hline Case $M-0-W$ & $0 / 48$ & $0 / 48$ & $0 / 48$ & 0 & 冬季 \\
\hline Case $\mathrm{M}-\mathrm{A}-\mathrm{S}$ & $8 / 48$ & $8 / 48$ & $8 / 48$ & 24 & 夏季 \\
\hline Case $M-A-W$ & $8 / 48$ & $8 / 48$ & $8 / 48$ & 24 & 冬季 \\
\hline Case M-B-S & $16 / 48$ & $16 / 48$ & $16 / 48$ & 48 & 夏季 \\
\hline Case $M-B-W$ & $16 / 48$ & $16 / 48$ & $16 / 48$ & 48 & 冬季 \\
\hline Case $\mathrm{M}-\mathrm{C}(1)-\mathrm{S}$ & $0 / 48$ & $0 / 48$ & $16 / 48$ & 16 & 夏季 \\
\hline Case $M-C(1)-W$ & $0 / 48$ & $0 / 48$ & $16 / 48$ & 16 & 冬季 \\
\hline Case $M-C(2)-S$ & $0 / 48$ & $16 / 48$ & $0 / 48$ & 16 & 夏季 \\
\hline Case $M-C(2)-W$ & $0 / 48$ & $16 / 48$ & $0 / 48$ & 16 & 冬季 \\
\hline Case $\mathrm{M}-\mathrm{C}(3)-\mathrm{S}$ & $16 / 48$ & $0 / 48$ & $0 / 48$ & 16 & 夏季 \\
\hline Case $M-C(3)-W$ & $16 / 48$ & $0 / 48$ & $0 / 48$ & 16 & 冬季 \\
\hline
\end{tabular}

表 8 空間平均温度結果

\begin{tabular}{c|c|c}
\hline Case 名 & 空間平均温度 $\left[{ }^{\circ} \mathrm{C}\right]$ & 取入外気との温度差 $\left[{ }^{\circ} \mathrm{C}\right]$ \\
\hline Case M-O-S & 25.6 & -3.0 \\
\hline Case M-O-W & 2.6 & +0.7 \\
\hline Case M-A-S & 26.3 & -2.3 \\
\hline Case M-A-W & 3.3 & +1.4 \\
\hline Case M-B-S & 29.6 & +1.0 \\
\hline Case M-A-W & 5.0 & +3.1 \\
\hline
\end{tabular}

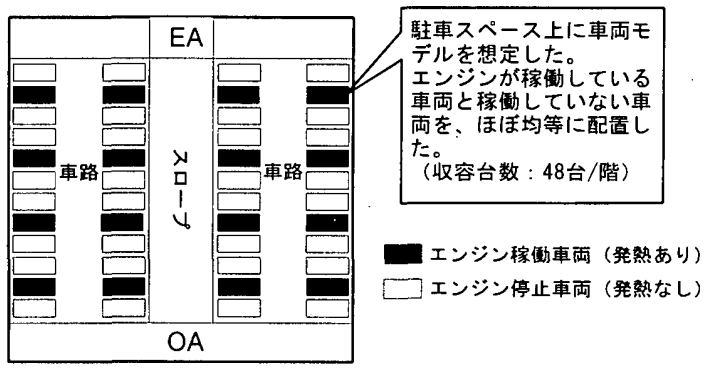

·想定した収容台数は総収容台数を 144 台(48 台/階)と設定した ${ }^{6}$ 。 図 9 発熱体(車両)の配置例(Case M-B-S および Case M-B-W) 


\section{（2）発熱車両が偏って存在する場合(図 12)}

規模の大きい駐車場では Case M-C(1)、Case M-C(2)および Case M-C(3)（16 台を単層階部分に発熱させた場合)のような偏った発熱 状況も考えられる。図 12 に示す、各ケースの呼吸域高さにおける空 気齢の結果においても、車両の発熱を想定した階においては、各階 同じ条件で発熱を想定したケース(Case M-B-S)と同様な傾向が見ら れた。また、発熱を想定した階による他階への影響は小さく、換気 性状は車両の発熱を考慮しない条件(CaseM-0-S) と同様な結果とな った。

冬季を想定したケース（Case M-C(1)-W、Case M-C(2)-W、Case $\mathrm{M}-\mathrm{C}(3)-W)$ についても夏季を想定したケースと同様な傾向を示した (図省略)。

各ケースの発熱車両台数は註 10 に示すように、駐車場の回転率(1 時間当たりの出入車数 $[$ 台 $/ \mathrm{h}] \div$ 総収容台数 [台])に基づいて想定して いる。すなわち、回転率の高いケース(Case M-B)は、商用施設など の出入台数が多い駐車場(1 台当たりの駐車時間が比較的短い駐車 場)に対応する。また、回転率の低いケース(Case M-A、Case M-C な ど)は事務所ビルなどの駐車残留台数 ${ }^{6)}$ が多い駐車場(1 台当たりの 駐車時間が長い駐車場)に対応する。
地下 1 階

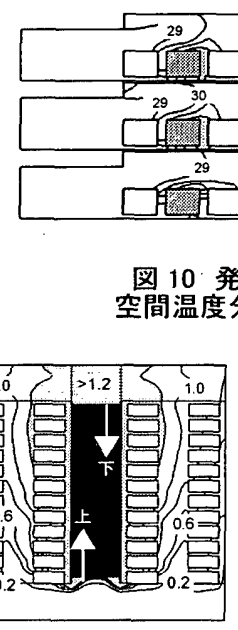

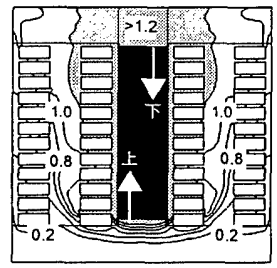

地下 2 階
(1) CaseM-0-S(夏季、発熱車両なし)

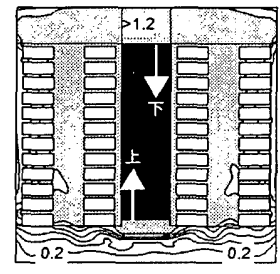

地下 3 階

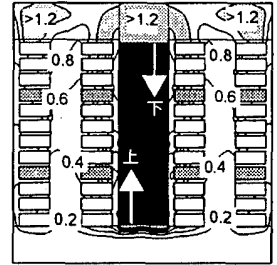

地下 2 階

(2) Case M-A-S (夏季)

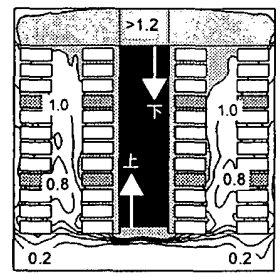

地下 3 階

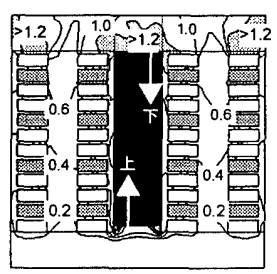

地下 3 媘 地: 発熱車両

地下 1 階

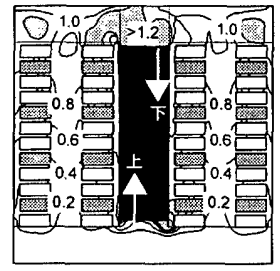

地下 2 階
(3) CaseM-B-S(夏季)

図 11 発熱車両がー様に分布した場合の

各階の空気撂分布(SVE3)

前述のように、各ケースでの自動車の浮力の影響は比較的大きく、 移流・拡散が活性化される。また浮力による影響と同様に、車の移 動に伴う擾乱も場内の拉散を促すものと考えられる。

\section{6.まとめ}

多層階地下駐車場に抽いて、等温状態を想定した機械換気設備の 給排気量がバランスしていない状態、および地盤からの熱移動や自 動車の発熱を想定した場合の換気性状をCFDにより検討し、以下の 知見を得た。

(1)Case 1(給気量=排気量)では、概ね各階の換気性状が同等となり、 滞留域の特定が容易でむる。このような場合、滞留域に対し誘引誘 導ノズルを設置するなど適切な換気計画が容易に行うことができる ものと考えられる。

(2)Case 2(給気量く排気量)では、給排気バランスの影響によって、他 の階から空気齢の值が大きい空気および新鮮外気がスロープに流れ 込み、各階の換気性状に差異が生じる。このような場合、換気計画 は比較的困難になる。

(3)Case 3(給気量>排気量)では、給排気バランスの影響によって各階 の余㮃空気(空気龄の值が大きい空気および新鮮外気)が上階へス口 一プを通して流れ、各階の換気性状に差異が生じる。Case 2 と同様 に換気計画が比較的困難になる。

(4)地盤からの熱流の影挈は最下階（地下 3 階）で見られ、夏季では 泠気が滞留し、冬季では浮力によって移流・拡散がやや活性化され る。

(5)車の発熱による影響は、地下駐車場内の移流・拡散をやや活性化さ せる。

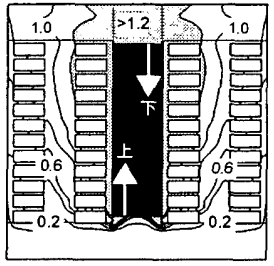

地下 1 階

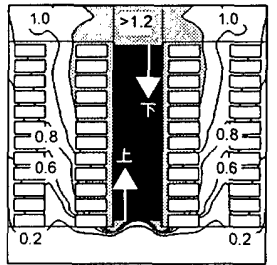

地下 1 階

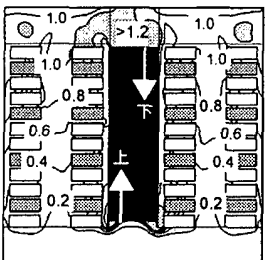

地下 1 階

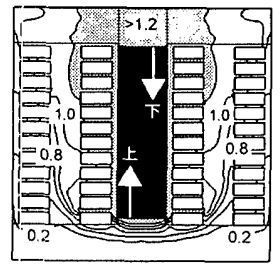

地下 2 階

(1) CaseM-C(1)-S(夏季)

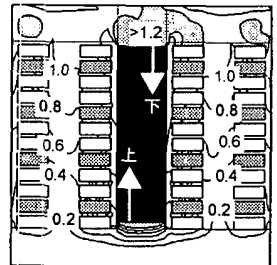

地下 2 階
(2) Case $M-C(2)-S$ (夏季)

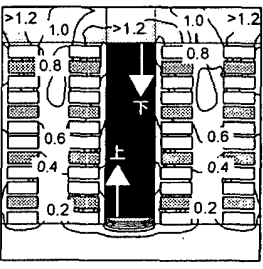

地下 3 階

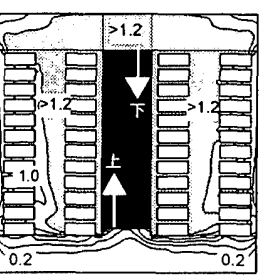

地下 3 階

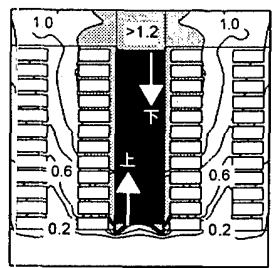

地下 2 階

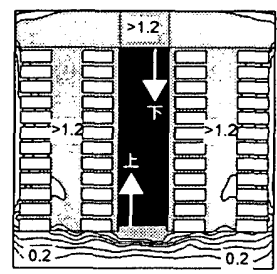

地下 3 階 （3）Case M-C(3)-S(夏季) 地:発熱車両 図 12 発剠車両が偏って分布した場合の 各階の空気秢分布(SVE3) 


\section{謝 辞}

本研究に行うに当たって、研究当時、東洋熱工業(株)·今井智将氏 および武蔵工業大学学生・水野谷康行氏(現在、日比谷総合設備(株)) からの多大なるご支援を頂いた。また、今回貴重なご意見を頂きま した東京都環境保全局・竹永祐二氏に対しここに記して謝意を表し ます。

\section{註 䣋}

註 1) 地下駐車場の換気方式として、第 1 種機械換気方式を採用することが多 く、給気ファン、排気ファンともに十分な調整をする必要があるが、これが できない場合は、給排気バランスに微妙なずれが生じる。

註 2）地上階開口部にかかる外部風圧によってもスロープに流れが生じ、換気 性状に影響を与えることが考えられる。しかし、外部風圧の影響は、本報で 扱った給排気バランスのずれによる影響と類似し、ほぼ同様な換気性状とな ると考えられる。

註 3) 本報では、駐車場のほぼ中央にスロープが配置されたものを『センター スロープ』、壁寄りに配置されたものを『サイドスロープ』と呼ぶ。また、上 りと下りのスロープが各々ある場合を『一方向』とし、上りと下りが $1 つ の$ スロープで併用されているものを『双方向』と呼ぶこととする。

註 4) 給気く排気とは排気量 $100 \%$ に対して給気量が $90 \%$ の負圧状態である。 また、給気〉排気とは給気量 $100 \%$ に対して排気量 $90 \%$ の正圧状態である。 Case2、Case3 ともに、換気量の $10 \%$ を減少させたが、その減少分は、地上階 開口部からの流出入する空気で確保されるものとした。

註 5) 地上階開口部の自然流入流出条件とは、境界面法線方向の圧力変化およ び速度変化が無いものとして扱った。

$$
\frac{\partial P}{\partial x_{n}}=0, \frac{\partial u}{\partial x_{n}}=0
$$

$P$ :圧力, $x_{n}$ :境界面法線方向座標, $u$ :流速

註 6) 図 3,4,5,8,11,12 に示す平断面の解析結果は地下 1 3 階までの呼吸域高さ $(\mathrm{FL}+1500 \mathrm{~mm})$ を想定している。

註7)各階の換気性状が同等であれば、ある階の滞留域を特定することにより、 他の階において誘引誘導ノズルの配置など、同様な換気計画が行うことがで きる(補図 1(a))。しかし、各階の換気性状に差異が生じた場合、各階每に滞留 域を特定する必要があり、換気計画も比較的困難になると思われる(補図 $1(\mathrm{~b}))$ 。 註 8) 地下階の壁や土壤からの熱流の取り扱いに関し、種々の検討がなされて

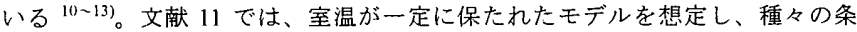
件、例えば、土㗜の熱伝導率および熱拡散率、室温設定の状態(椧暖房)、気 候、室形状(床や壁)、躯体の熱抵抗(断熱材を含む)や構造物の地中深さなどを 想定し、また外気温など外乱による熱的影響を単弦波周期的変動として扱い、 地盤からの熱流を算定している。また、他の様々な方法(モデルルームでの実 測、ASHRAE Method, European Standard やMitalas)とも比較している。本報 では、別途、補図 2 に示寸地盤を含む 2 次元断面を対象として年間の温度変 化を差分解法により求めた。 4 章、 5 章の CFD 解析では、この結果に基づく 熟流を地盤に接する壁や床に与えている。補図 2 に示すように、地下駐車場 の最下階床面は地下 $12 \mathrm{~m}$ にあるとし、地下駐車場を囲む地盤は $10 \mathrm{~m}$ の範囲を 計算対象とした。本計算の前に 5 年間の助走期間をおいて地中温を安定させ、 6 年目の計算值により熱流を算出した。また、地下水および雨水など水分移 動については考慮していない。各境界条件の扱いは、地表面では日射の影響 は考慮せず外気温度を設定、壁から $10 \mathrm{~m}$ の境界（土中深さ毎の温度）および 林から $10 \mathrm{~m}$ の境界（不易層： $15.3^{\circ} \mathrm{C}$ (東京年平均気温)）は文献 14 を参考に想 定した。地上階は考慮せず地下 1 階駐車場の天井面は完全断熱とする。地下 駐車場内空気に接する境界では総合熱伝详率 $\left(9.3 \mathrm{~W} / \mathrm{m}^{2} \cdot \mathrm{K}\right)$ を用いる。地下駐車 場内の換気回数は法令により定められている10[回/h]とした。また想定した 地盤や躯体の物性に関しては文献 15 を参考に想定した。 4 章、5 章における 解析では各階の地盤に接する壁面および最下階(地下 3 階)の床面に対して、 上記の方法により算出した熱流を平均化し、最大值および最小值をそれぞれ 冬季および夏季の熱流として与えた（補図 3)。地下 1·2 階の床・天井および 地下 3 階の天井に関しては完全断熱熱条件とした。

註 9) ガソリン車の場合、燃料が燃焼した場合の全エネルギー $(46 〜 48 \mathrm{MJ} / \mathrm{kg})$ の約 $60 \%$ がエンジンが位置するボンネット部分および排気ガスとして排熱さ れると考えられている ${ }^{13)}$ 。また、別途行った排気ガスの排気温度および排気
風量の測定により、排熱に占める排気ガスの熱量は以下に示す試算により $2.1 \%$ 程度と小さく、排気ガス以外（うボンネット部分）からの排熱が大きい ことから、5 章の CFD 解析では、自動車の発熱をボンネット部分に対して、 $1300 \mathrm{cc} \sim 3000 \mathrm{cc}$ クラスのアイドリング時における平均燃費 $(\doteqdot 0.9 \ell / h)^{16)}$ を参 考とし、車両 1 台当たり $5.3 \mathrm{~kW}$ の発熱量があると推定し、これを与えて検討 した。

【排気ガスによる排熱量の圾算】

排気ガスによる排熱量は補表 1 および次式により試算することができる。 補表 1 実測による排気ガス温度および排気ガス量

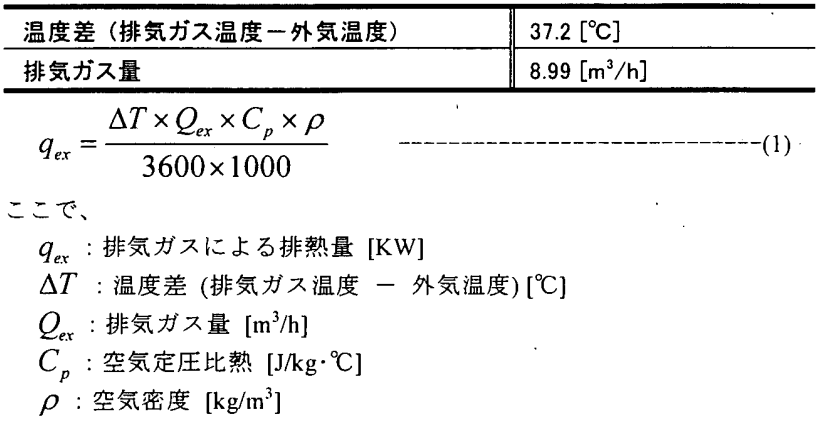

註 10)地下駐車場における発熱している自動車台数に関しては次式によって 想定することができる。

$N_{h}=R \cdot\left(T_{i}+T_{r}+T_{h}\right) / 60 \cdot N_{i}$ ここで、

$N_{h}:$ 発熱している自動車台数 [台]

$R$ : 回転率 $[1 / \mathrm{h}]($ 単位時間当たりの出入車両数 $[$ 台 $/ \mathrm{h}] /$ 総収容台数 [台 $])$

$T_{i}:$ アイドリング時間[min]

$T_{r}:$ 走行時間 $[\mathrm{min}]$

$T_{h}$ : エンジン停止後の放熱時間[min]

$N_{1}$ : 総収容台数 [台]

5 章に打ける解析では、発熱台数の設定に関しては、式(2)を用い、 $T_{i}+T_{r}+T_{h}$ を 20 分と想定し、 $R$ (回転率) $=0.35$ (CaseM-C $(1) \sim$ CaseM-C $\left.(3)\right)$ ， 0.50 (CaseM-A)、1.0(CaseM-B)の発熱台数を算定した。

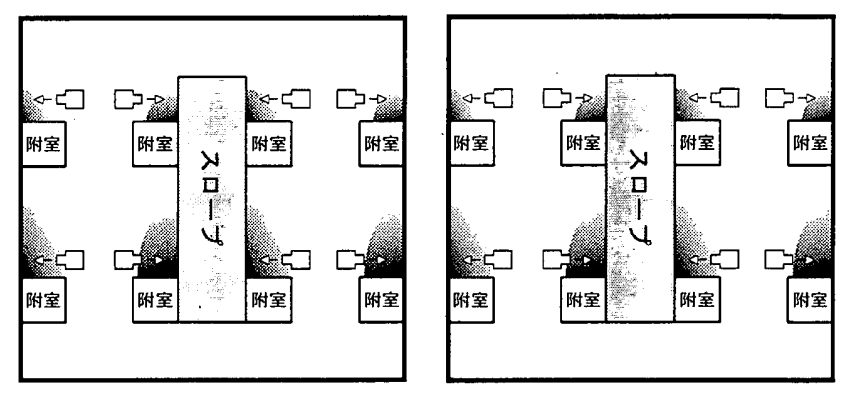

ある階の換気性状とノズルの配置

他の階の愌気性状とノズルの配置

(a) 各階の換気性状が同等な場合の換気計画

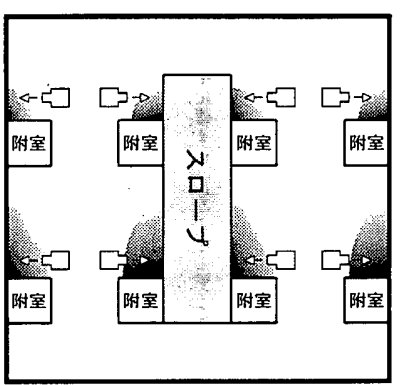

ある階の換気性状とノズルの配置

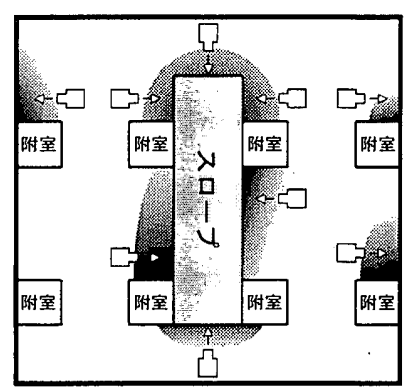

他の階の換気性状とノズルの配置 （b）各階の換気性状に差異が生じた場合の換気計画

—つ:誘引誘導ノズルおよび吹出方向

補図 1 換気計画例 

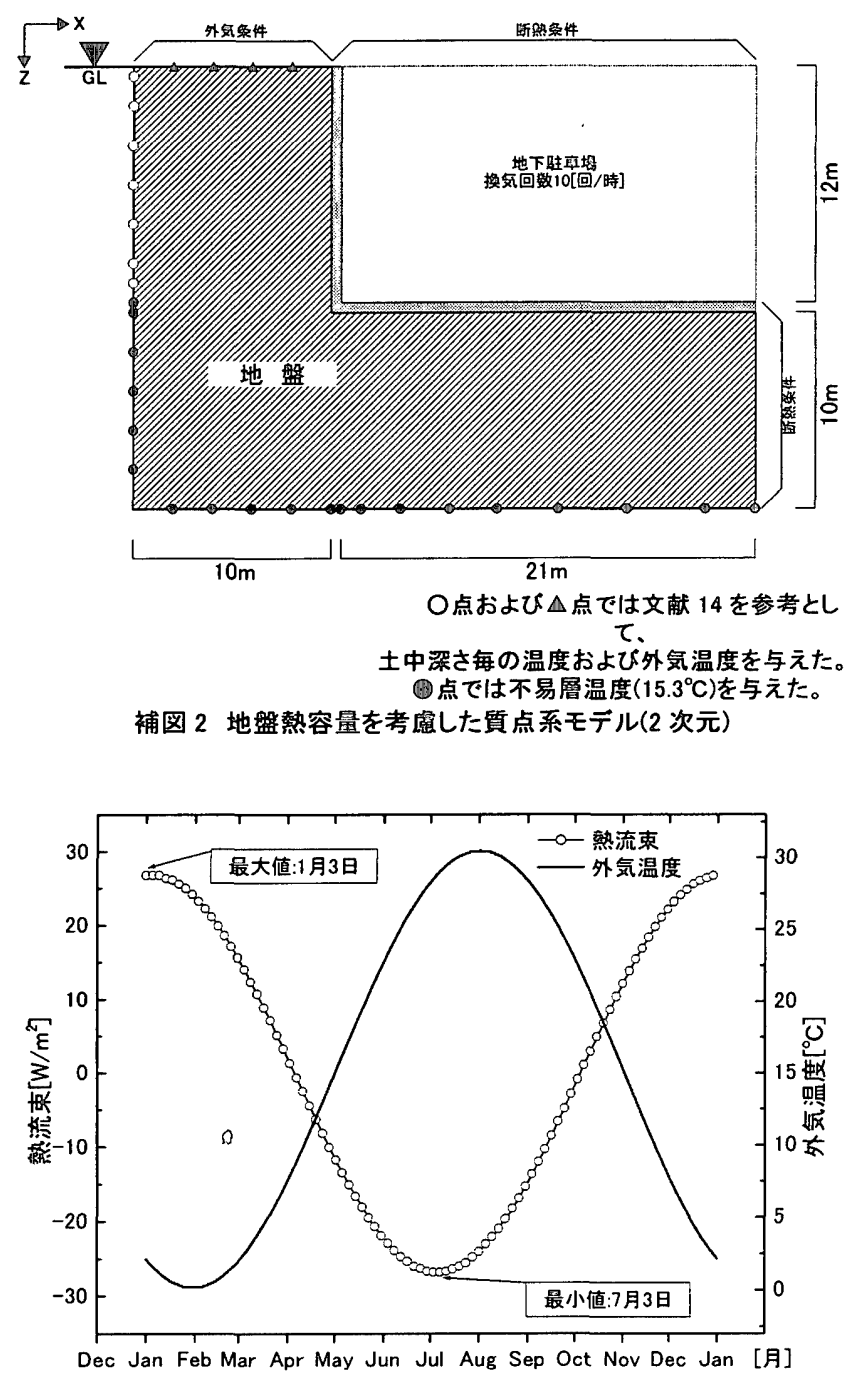

補図 3 差分計算によって求めた壁体表面の非定常熱流
参考文南

1)吉野一、近藤请史、今井智将、田所祐人他：地下駐車場における換気性状 換気効率の研究(その 5)給排気バランスが換気性状に与える影罌に関する CFD 解析、日本建築学会学術講演梗概集、pp617-618、2000 年9月

2)今井智将、近藤靖史、吉野一、田所祐人他：地下駐車場における換気性状 · 換気効率の研究(その 6)温度分布が換気性状に与える影響に関する CFD 解析、 日本建築学会学術講演梗概集、pp619-620、2000 年 9 月

3)水野谷康之、近藤靖史、吉野一、今井智将、田所祐人：地下駐車場における 換気性状 - 換気効率の研究、多層階地下駐車場の換気性状に関する CFD 解析、 日本建築学会関東支部研究摯告集、pp233-236、2000 年 3 月

4)吉野一、近藤靖史、今井智将、田所祐人他：地下駐車場における換気性状 換気効率の研究(その 7)給排绿バランスの影響を考㦄した CFD 解析、空気調和. 衛生工学会学術講演会講演諭文集、pp597-600、2000 年 9 月

5)今井智将、近藤崝史、吉野一、田所祐人他：地下駐車場における換気性状 換気効率の研究(その 8)温度分布の影響を考慮した CFD 解析、空気調和·衛生工 学会学術講演会講演論文集、pp601-604、2000 年 9 月

6)金原正、奥村修一、矢是栄士士、斎藤圭弘：駐車場の計画と設計、pp95-106、 鹿島出版会、1992 年

7)近藤靖史、吉野一、今井智将、田所祐人、横田雄史：地下駐車場における換 気性状・換気効率の研究(その1) 実測および CFD 解析による地下駐車場内の換 気性状の検討、日本建築学会計画系論文集、No.549、2001年11月 8)村上周三：CFD による建築·都市の環境設計工学、pp34、2000年 9)村上周三、加藤信介：新たな換気効率指標と三次元乱流数值シミュレーションによる 算出法、空気調和·衛生工学会論文集、No.32、1986 年 10 月 10)赤坂裕:士に接する床·壁面の熟取得、日本建築学会学術講演梗概集、pp497 $-498 、 1980$ 年 9 月

11)松本真一、Peter Sobotka、吉野博:地下室の簡易熱負荷計算法に関する比較研 究(その 3)Mitas European Standard,ASHRAE の方法及び 2 次元有限要素法による 月平均熱損失の予測值と実测值の比較、日本建築学会学術講演梗概集、pp519 $-520 、 1994$ 年 9 月

12)三野誠士、小椋大輔、松下敬幸、水烟雅行、松本衛、安本峰樹、山口裕之: 地下空間とその周辺地盤の熱·水分性状の実験及び解析(その 13、その 14) 日本 建築学会学術講演梗概集、pp307-400、1999 年 9 月

13)日本伝熱学会編 : 環境と省エネルギーのためのエネルギー新技術大系、pp611、 1996 年

14)宇田川光弘 : パソコンによる空気調和計算法、オーム社、1986 年 15) 日本機械学会、伝熱工学凟料 第 4 版、pp320-322、丸善、1986 年 16)平成 8 年度東京都環境保全局委託調查(自動車排出大気污染物質の排出調查)、 現代企画社、1997 年 